\title{
POLA KEPEMIMPINAN DI PONDOK MODERN BABUSSALAM DESA MOJOREJO KECAMATAN KEBONSARI KABUPATEN MADIUN TAHUN 2008-2013
}

\author{
Mona Bonita \& Anjar Mukti Wibowo*
}

\begin{abstract}
Abstrak
Penelitian ini bertujuan penelitian untuk mengetahui pola kepemimpinan di Pondok Modern Babussalam Desa Mojorejo Kecamatan Kebonsari Kabupaten Madiun tahun 2008 sampai 2013. Penelitian ini berjenis penelitian kualitatif deskriptif, sumber yang digunakan berasal dari sumber primer dan sekunder, teknik penggalian sumber dengan wawancara dan observasi, penelitian ini bentuk validasi yang digunakan untuk menguji kebenaran data dengan menggunakan trianggulasi sumber penelitian, dan tahap akhir adalah verifikasi. Berdasarkan penelitian dapat diperoleh bahwa perkembangan Pondok Modern Babussalam mengalami jatuh bangun, penuh dengan tantangan baik dari dalam maupun dari luar, akan tetapi dengan ketabahan dan mujahadah pendiri serta pengasuh pondok modern, pondok ini dapat dikenal masyarakat luas dan banyak yang berminat menuntut ilmu di dalamnya, yang pada akhirnya pondok ini mengalami kejayaan. Kejayaan yang telah diraih Pondok Modern Babussalam mengalami kemunduran ditinjau dari kuantitas santrinya, disamping permasalahan tersebut yaitu wafatnya pendiri, sehingga kehilangan sosok pemimpin. Kepemimpinan akhirnya dilanjutkan oleh keponakan pendiri yang bernama Ust. Ahmad Fauzani Effendy, S.Ag, M.Pd.I. Kuantitas santri semakin tahun semakin turun, pengurus serta pemimpin berusaha sekuat tenaga demi kelangsungan pondok, yang pada akhirnya diadakan reuni akbar semua alumni, dari reuni tersebut dihasilkan keputusan untuk dibentuknya badan wakaf, keputusan badan wakaf yaitu dibentuknya tiga pimpinan, yaitu Ust. Ahmad Fauzany Effendi, Ust. Burhanuddin, Ust. Ahmadi MS.
\end{abstract}

\section{Kata Kunci : Pola Kepemimpinan, Pondok Pesantren}

\section{Pendahuluan \\ Pondok merupakan lembaga} pendidikan yang berasaskan Islam yang di dalamnya mengajarkan pelajaran agama. Menurut historisnya, pesantren telah tumbuh sejak ratusan tahun yang lalu dan telah mengalami dinamika dari yang tradisional maupun yang modern. Hal ini terlihat pada perkembangan pondok pada saat ini ada beberapa pondok yang mengajarkan ilmu agama di lengkapi dengan materi pelajaran umum, jadi dalam pelaksanaan pendidikannya pondok ini mengikuti ujian negara. Mata pelajaran tertentu mengikuti kurikulum Departemen Agama yang dimodifikasi oleh pesantren yang bersangkutan sebagai ciri kepesantrenan (Haidar Putra Daulay, 2009:20.

Pesantren sebagai lembaga pendidikan Islam tadisional, secara historis telah ada sejak tahun $1630 \mathrm{M}$ dan hingga kini masih bertahan (Ahmad Muthohar, 2007:3), hal ini terlihat pada perkembangan pesantren dewasa ini yang mulai diminati oleh masyarakat, sehingga banyak pesantren yang didirikan, khususnya di daerah Jawa yang sangat mendominasi 
keberadaan pondok atau pesantren. Pesantren merupakan lembaga pendidikan yang tua di Indonesia karena sudah ada sejak zaman penjajahan, yang mana pada masa penjajahan segala bentuk pendidikan sangatlah sulit, karena dilarang oleh penjajah, namun dengan berbagai metode dilakukan walaupun dengan sembunyisembunyi akhirnya ajaran-ajaran itu tersampaikan pada muridnya. Dinamika yang mengharukan dan penuh perjuangan demi bangsa Indonesia. Eksistensi pesantren masih dapat kita nikmati hingga saat ini, karena kita dapat melihat dan menikmati keberadaanya. Pondok Modern Babussalam merupakan contoh eksistensi pondok pesantren, yang dapat kita nikmati pada saat ini.

Kemajuan ilmu pengetahuan dan teknologi membawa dampak terhadap bentuk pesantren, bukan berarti ciri khas pondok hilang, namun pondok pesantren tetap merupakan lembaga pendidikan Islam yang tumbuh dan berkembang dari masyarakat untuk masyarakat. Tipe Pondok Pesantren yang berkembang dalam masyarakat yaitu, Pondok Pesantren Tradisional dengan pola pengajaran halaqoh (penghafalan) yang mempelajari kitab yang ditulis oleh ulama abad ke 15 dengan menggunakan bahasa Arab. Kedua adalah Pondok Pesantren Modern dalam penerapan sistem belajarnya menggunakan kelas-kelas belajar yang baik dalam bentuk madrasah atau sekolah. Kuikulum yang di pakai adalah kurikulum sekolah dan madrasah yang berlaku secara nasional, yang terlihat perbedaannya pada porsi pendidikan agama dan bahasa Arab yang lebih menonjol sebagai kurikulum lokal (Bahri Ghazali, 1996:15). Babussalam merupakan tipe yang kedua yaitu Pondok Pesantren Modern sehingga disebut Pondok Modern Babussalam.

Pondok Modern Babussalam merupakan pondok yang mementingkan pendidikan dari pada pengajaran dengan, arah tujuan : kemasyarakatan, hidup sederhana, tidak berpartai dan tujuan akhirnya ibadah talabul ilmi (Menuntut ilmu), ilmu tidak ada ujungnya. Sebagai akibat dari pada ajaran-ajaran ini maka salah satu aspek penting dari pada sistem pendidikan Pesantren ialah tekanan pada murid-muridnya untuk terus menerus berkelana dari satu pesantren ke pesantren yang lain (Zamakhsyari Dofier, 1982:25).Spirit tolabulilmi (Menuntut ilmu) di Pondok Modern Babussalam juga di tanamkan pada santri-santrinya, tanpa ada dikotomi ilmu, sehingga mereka berhak mempelajari ilmu apapun dan dimanapun tidak harus di Pesantren. Perkembangan paham ini merupakan salah satu dari motto Pondok Modern Babussalam yaitu berbudi tinggi, berbadan sehat, berpengetahuan luas, berpikir bebas.

Pondok merupakan wadah pendidikan agama yang mana di dalamnya juga di butuhkan Pemimpin, untuk 
mengembangkan pondok tersebut, baik berupa kwalitas pendidikan sampai di bidang pembangunannya. Dengan demikian, pemimpin dalam konteks pendidikan mempunyai elan vital dalam aplikasinya untuk membawa pendidikan pada wilayah yang di harapkan (Baharuddin dan Umiarso, 2012:71). Selain itu Pimpinan pondok adalah seorang yang sangat di patuhi dan dianut karena beliu adalah suri tauladan, dan beliau di panggil dengan sebutan Kiai. Beliaulah orang nomor satu di Pondok, karena setiap keputusan dan apapun itu harus di ketahui oleh beliau, mulai dari kegiatan santri sampai administrasi yang ada di Pondok tersebut.

Pondok Modern Babussalam didirikan dan pimpin oleh seorang alumni dari Pondok Modern Darussalam gontor, yang bernama KH. Martoyo BA, di masa kepemimpinan beliau, Pondok Modern Babussalam mengalami masa keemasan karena jumah santrinya banyak mencapai ratusan, dan setelah beliau wafat di gantikan oleh keponakannya yang bernama Kiai Ahmad Fauzany Effendy S.Ag. M.Pd.I. Setelah masa transisi pondok ini mengalami banyak perubahan, semakin hari santrinya berkurang. Sehingga diadakan suatu kumpulan alumni dan terbentuklah badan wakaf, dan pada akhirnya menghasilkan keputusan bersama di ambil tiga pimpinan di Pondok Modern Babussalam. Zamarkhsyari Dhofier, berpandangan:
"Pada kebanyakan pesantren, dahulu komplek merupakan milik kyai, tetapi sekarang, kebanyakan pesantren tidak semata-mata dianggap milik kyai saja, melaikan milik masyarakat. Hal ini disebabkan karena para kyai memperoleh sumber-sumber keuangan untuk mengongkosi pembiayaan dan perkembangan pesantren dari masyarakat. Banyak pula kompleks pesantren yang kini sudah berstatus wakaf, baik yang diberikan oleh kyai yang terdahulu, maupun wakaf yang berasal dari orang-orang kaya. Walaupun demikian, para kyai masih tetap memiliki kekuasaan mutlak atas kepengurusan pesantren tersebut."

Dibentuknya badan wakaf yang memutuskan untuk kepemimpinan di Pondok Modern Babussalam dibentuk tiga pimpinan yaitu Ustad Ahmad Fauzani Effendy, Ustad Burhanuddin dan Ustad Ahmadi MS. Fungsi tiga pimpinan ini untuk mengurus semua yang ada di pondok tersebut, supaya bisa mencapai masa keemasan yang pernah diraihnya dahulu. Hal yang mendasari keputusan badan wakaf adalah anggapan dengan adanya tiga pimpinan, pondok ini akan selaras kembali, karena tanggungan seorang pemimpin di bebankan kepada tiga orang, sehingga meringankan tugas Pimpinan.

Pondok Modern Babussalam mempunyai bagian-bagian organisasi seperti Staff. Riayah (Bagian Pengasuhan), Kulliyatul Mu'allimin Al-Islamiyah (Bagian 
pengajaran), Mabikoord (Kepramukaan), Bagian Perpustakaan, Bagian Laboratorium, Bagian Administrasi, dan Bagian Dapur. Setiap bagiannya mempunyai program kerja dan tugas-tugas setiap bagian, sehingga mempermudah Pimpinan dalam mengontrol dan mengawasi bagian-bagian yang terdapat di Pondok Modern Babussalam.

Keberadaan Pimpinan di pondok dapat diibaratkan sebagai raja di kerajaan kecil, kedudukan pimpinan sangat diagungkan, tidak ada yang berani membantah beliau, semua santri tunduk dan patuh. Pimpinan di dalam pondok di sebut Kiai yang merupakan tokoh sentral sebagai penggerak dalam mengemban dan mengembangkan pesantren sesuai dengan pola yang dikehendaki. Kemajuan dan kemunduran pondok pesantren terletak pada kemampuan kiai dalam mengatur pelaksanaan pendidikan di dalam pesantren. Pimpinan atau Kiai merupakan

\section{Tujuan dan Manfaat Penelitian}

Berdasarkan pada rumusan permasalahan tersebut diatas, maka yang menjadi tujuan penulisan ini dalam melakukan penelitian yaitu untuk mengungkap pola kepemimpinan di Pondok Modern Babussalam Desa Mojorejo Kecamatan Kebonsari Kabupaten Madiun tahun 2008 sampai 2013.

Dari hasil penelitian tersebut di harapkan diperoleh hasil berupa gambaran penguasa baik fisik maupun non fisik. Faktor utama perkembangan dan menemukan kemapanan pesantren karena adanya kiai yang selalu tertanam rasa memiliki, serta keikhlasan seorang Kiai (Bahri Ghazali, 1996:22).

Pondok Modern Babussalam memiliki kepemimpinan yang khas dan unik terdapat tiga pimpinan di pondok ini, masing-masing pemimpin memiliki kewenangan yang sama, sehingga terbangun Kepemimpinan kolektif. Peneliti tertarik untuk melakukan penelitian tentang Pola Kepemimpinan di Pondok Modern Babussalam Desa Mojorejo Kecamatan Kebonsari Kabupaten Madiun.

Penelitian ini mengkaji tentang pola kepemimpinan di Pondok Modern Babussalam yang terletak di Desa Mojorejo Kecamatan Kebonsari Kabupaten Madiun pada tahun 2008 sampai 2013. Hal ini sebagai batasan kami supaya mempermudah peneliti dalam penelitiannya.

tentang seberapa jauh pola kepemimpinan pemimpin di pondok modern Babussalam.

Kegunaan penelitian ini meliputi halhal sebagai berikut :

1. Bagi Peneliti

Dapat menambah pengalaman maupun wawasan bagi peneliti tentang kepemimpinan dan mengembangkan ketrampilan dalam menyusun karya ilmiah.

2. Bagi Ikip PGRI Madiun

Bagi IKIP PGRI Madiun sebagai tempat para intelektualis menimba ilmu, 
semoga dapat dijadikan sebagai tambahan referensi, bahan bacaan yang bermanfaat bagi para mahasiswa, serta sebagai bahan perbandingan dengan tulisan lain yang serupa.

3. Bagi Pondok Modern Babussalam

\section{Tinjauan Pustaka}

\section{A. Kepemimpinan}

1. Pengertian Kepemimpinan

Secara etimologi, kepemimpinan berasal dari kata dasar pemimpin. Dalam bahasa Inggris leadership yang berarti kepemimpinan, dari kata dasar leader berarti pemimpin dan akar katanya to lead yang terkandung beberapa arti yang saling erat berhubungan: bergerak lebih awal, berjalan di awal, mengambil langkah awal, berbuat paling dulu, mempelopori, mengarahkan pikiran pendapat orang lain, membimbing, menuntun dan menggerakkan orang lain melalui pengaruhnya (Baharuddin dan Umiarso, 2012:47). Pemimpin merupakan orang nomor satu di golongannya, seorang yang mempunyai kelebihan di bandingkan anggotanya, sehingga mampu menciptakan perubahan yang positif untuk golongannya, serta mampu menjadi teladan yang di segani dan ditaati oleh anggotanya.

Seiring perkembangan era definisi pemimpin dan kepemimpinan mengalami perubahan dan perkembangan. Sejarah kepemimpinan pun menceritakan tentang negara dan bangsa sebenarnya berkisar
Dapat dipergunakan sebagai sumbangan pemikiran yang mungkin dapat dijadikan bahan pertimbangan bagi para pemimpin dalam menentukan langkah demi perkembangan pondok, dan terjaga keteratran dan keharmonisannya

pada tokoh-tokoh, pemimpin-pemimpin pemerintahan atau negara, semenjak zaman dahulu dan sekarang. Istilah leader dan leadership baru dikenal sejak tahun 1930. Tergolong ke dalam pimpinan adalah Pemimpin (Leader), pemimpin mempunyai jiwa kepemimpinan, bukan hanya didapatkan pada seorang seperti kepala (ketua), akan tetapi melekat pada orangnya, meskipun ia tidak diangkat sebagai pemimpin. Kepala (head) Pemimpin yang diangkat secara resmi oleh atasan biasanya disertai dengan surat keputusan. Ketua (Chairman) yang biasanya tidak perlu disertai pengangkatan resmi oleh atasan (Widjaja, 1985:9).

Berdasarkan beberapa definisi kepemimpinan tersebut dapat di simpulkan bahwa kepemimpinan adalah suatu kegiatan mempengaruhi orang lain agar orang tersebut mau bekerja sama untuk mencapai tujuan yang telah di tetapkan (Baharuddin dan Umiarso, 2012:48). Kepemimpinan merupakan kemampuan untuk mempengaruhi perilaku individuindividu, pengaruh tersebut berupa motivasi, arahan atau petunjuk sehingga mencapai apa yang telah di tetapkan. 
Oleh sebab itu pemimpin diharapkan memiliki kemampuan dalam menjalankan kepemimpinannya karena apabila tidak memiliki kemampuan memimpin, tujuan yang ingin dicapai tidak akan tercapai secara maksimal. Kemampuan tersebut dapat berupa kemampuan berpikir, kerohanian dan dalam kejasmanian (Widjaja,1985:25). Kepemimpinan dalam organisasi merupakan sugesti untuk memutar roda pemberdayaan organisasi tersebut, yang berarti peran sentral dalam organisasi tidak pernah lepas dari kinerja seorang pemimpin untuk menggerakkan potensi-potensi yang ada dalam organisasi, sehingga pemimpin harus mempunyai power untuk menggerakkan organisasi yang dipimpinnya.

Kepemimpinan seorang Kiai di dalam Pondok Pesantren penting artinya bagi kelangsungan hidup dari suatu Pesantren, sebagai lembaga pendidikan Islam Pesantren mempunyai tanggung jawab untuk mencetak dan membangun generasi muda yang sehat jasmani maupun rohani. Amanat yang suci ini merupakan tanggung jawab yang berat bagi lembaga pendidikan ini. Untuk mencapai hal tersebut tersebut, hendaknya mempunyai visi dan misi serta konsep yang menjadi pedoman semua staff dan bagian. Pemimpin merupakan fakor penenu dalam kesuksesan atau gagalnya suatu organisasi dan usaha (Baharuddin dan Umiarso, 2012:25).

2. Fungsi Kepemimpinan
Kelompok atau organisasi formal ataupun informal memerlukan pemimpin, dan pengangkatan dapat melalui surat keterangan ataupun diambil mufakat bersama. Di perlukan seorang pemimpin karena sebagai teladan, dan orang nomor satu di dalam kelompoknya atau organisasinya. Sifat-sifat utama seorang pemimpin adalah kemampuan merencanakan, kemampuan inisiatif atau bertindak, kemampuan memecahkan masalah, kemampuan menerima tanggung jawab, dan kemampuan interaksi sosial (Widjaja, 1985:20). Berbagai sifat tersebut sebagai dasar pemimpin mengemban amanatnya, karena peran, tugas serta fungsinya sangatlah berat. Berdasarkan sifat-sifat tersebut dapat di bedakan menjadi 6 fungsi pokok kepemimpinan, keenam tersebut adalah :

a. Fungsi Instruktif

Setiap pemimpin perlu memiliki kemampuan dalam memberikan perintah dengan jelas, agar terlaksana dengan baik dan sesuai perintah, karena instruktif merupakan komunikasi satu arah yaitu pimpinan kepada anggota atau bawahannya. Pemimpin harus menetapkan apa, bagaimana, bilamana, dan di mana suatu perintah dilaksanakan (Hadari Nawawi, 1993:143). Pada hakikatnya Pemimpin adalah sebagai pemegang konsep dan yang melaksanakan adalah anggotanya, hal ini merupakan hubungan atau interaksi yang terjadi di organisasi. Pemimpin merupakan 
konseptor yang menetapkan apa yang harus dilaksanakan.

Instruksi atau perintah yang dilakukan seorang pemimpin merupakan aplikasi dari suatu gaya kepemimpinan, kepemimpinan yang efektif yaitu mampu mempengaruhi, mengarahkan dan menggerakkan orang-orang yang dipimpin sesuai dengan situasi dan kondisi supaya mereka mau bekerja dengan penuh semangat dalam mencapai tujuan organisasinya. Kepemimpinan Instruktif mempunyai ciri-ciri yaitu, memberi pengarahan secara spesifik tentang apa, bagaimana, dan kapan kegiatan dilakukan, kegiatan lebih banyak diawasi secara ketat (Baharuddin dan Umiarso, 2012:53)

Konseptor dalam organisasi adalah pemimpin, dengan adanya perintah dari pimpinan kepada anggota merupakan proses dari tujuan organisasi tersebut untuk mencapai apa yang telah di tetapkan. Komunikasi yang baik dan jelas sangat mempengaruhi hasil dari apa yang telah di perintahkan, hendaknya seorang pemimpin mempunyai interaksi yang baik kepada anggotanya. Bawahan atau anggota harus menjalakan apa yang telah di perintahkan, karena Pemimpin memiliki kekuasaan untuk meminta bawahan dan bawahan mempunyai kewajiban untuk menuruti atau mematuhinya (Wahjosumidjo, 2005:21).

b. Fungsi Konsultatif

Fungsi ini bersifat komunikasi dua arah, yang berlangsung dalam bentuk interaksi antara pemimpin dan anggota organisasinya. Fungsi konsultatif mempunyai hubungan yang erat dengan fungsi instruktif, karena dalam menjalankan perintah terkadang anggota kurang memahami perintah pemimpin, dalam hal ini seorang pemimpin harus memberi dorongan dan menjelaskan kembali apa yang telah di perintahkan, supaya meminimalkan kesalahan dalam bertugas. Fungsi ini seorang pemimpin memberikan saran dalam pemecahan masalah serta memberikan sumbangan informasi dan pendapat (Wahjosumidjo, 2005:41).

Pemimpin perlu menyimak berbagai persoalan, aspirasi, pendapat, perasaan, data, informasi dan lain-lain yang diungkapkan anggotanya. Konsultasi dilakukan untuk mendapatkan feed back (umpan balik), dalam rangka memperbaiki dan menyempurnakan keputusan (Hadari Nawawi, 1993:144). Kebijakan pemimpin mempengaruhi wibawa pemimpin, sehingga pemimpin harus bisa bersikap sebagai wadah atau payung kepada anggotanya.

Ketrampilan sebagai konsultan hendaknya dimiliki oleh pemimpin, pemimpin merupakan ujung tombak dalam organisasi. Dorongan serta solusi yang baik dan tepat adalah faktor yang mempengaruhi efektifitas seorang pemimpin. Pemimpin harus mampu menciptakan keseimbangan, mampu menentukan mana yang diprioritaskan dan mana yang ditunda (Widjaja, 1985:51). 
c. Fungsi partisipasi

Tugas pemimpin dalam fungsi partisipatif adalah mengerahkan tim kepada ketercapaian konsensus (Baharuddin dan Umiarso, 2012:54). Tujuan adalah sebagai pedoman dalam organisasi, segala aspek mengacu atau berkiblat kepada tujuan organisasi, yang pada akhirnya menjadi pondasi pemimpin dalam melaksanakan tugasnya untuk mengerahkan timnya, dan membina team work yang solid. Kesadaran berorganisasi harus dimilki oleh setiap komponen yang ada mulai dari pimpinan sampai bawahannya, pemimpin harus siap memimpin dan bawahan harus siap dipimpin.

Pemimpin harus berusaha mengaktifkan setiap anggota organisasinya, sehingga terdorong untuk berkomunikasi. Setiap anggota didorong untuk aktif dalam melaksanakan tugas pokoknya, sesuai dengan posisi atau jabatan dan wewenang masing-masing. Fungsi partisipasi berarti kesediaan pemimpin untuk ikut serta dalam pelaksanaan berbagai keputusan (Hadari Nawawi 1993:146). Keikutsertaan pemimpin dalam pelaksanaan keputusan dapat menjadi motivasi anggota dalam menjalankan tugasnya, serta menghilangkan persepsi pemimpin diktator, yang kerjanya hanya menyuruh tanpa ada andil di dalamnya. Selain itu pemimpin dapat mengawai langsung semua tugas yang telah dibebankan kepada bawahannya.

d. Fungsi Delegasi
Delegasi adalah melimpahkan sebagian wewenang kepada orang yang dipercayainya seperti staff, divisi atau bawahannya, hal ini ditujukan untuk mempermudah pekerjaan pemimpin dalam mengemban tugasnya, fungsi delegasi juga bisa disebut pembagian tugas terhadap staff dan bahawahannya. Tugas pemimpin dalam fungsi delegasi yaitu memberikan pengarahan bila diperlukan saja, penyerahan tanggung jawab kepada bawahan untuk mengatasi dan menyelesaikan tugas (Baharuddin dan Umiarso, 2012:54). Menurut Widjaja, (1993:18) berpendapat:

"Kekuasaan atau wewenang adalah hak seorang pemimpin untuk mengambil tindakan yang diperlukan agar tugas serta tanggung jawabnya dapat dilaksanakan dengan baik. Pendelegasian adalah penyerahan, jadi pendelegasian wewenang berarti adanya penyerahn sebagian hak untuk mengambil tindakan yang diperlukan agar tugas serta tanggung jawabnya dapat dilaksanakan dengan baik dari pejabat satu kepada pejabat lainnya."

Pelimpahan wewenang dalam menetapkan keputusan mungkin diberikan dengan persyaratan tertentu, pelaksanaan fungsi ini tergantung kepercayaan pimpinan. Pemimpin harus mampu memberikan kepercayaan, sedang penerima delegasi harus mampu memelihara kepercayaan (Hadari Nawawi, 1993:147). Kepercayaan yang terjaga dengan baik 
antara pemimpin dan bawahan akan menimbulkan keselarasan dalam organisasi, organisasi akan berjalan dengan harmonis.

Kekuasaan yang telah dipercayakan kepada bawahannya, hendaknya terus diawasi oleh pemimpin, supaya sesuai dengan perintahnya, apabila pemimpin kurang berperan aktif maka akan mempengaruhi wibawa seorang pemimpin. Pemimpin secara aktif menggunakan peranan kepemimpinannya daripada menyerahkan kepemimpinan kepada yang lain (Wahjosumidjo, 2005:26). Menunjukkan perilaku yang bersahabat saling adanya kepercayaan, saling menghormati, dan hubungan yang hangat di dalam kerja sama antara pemimpin dengan angota-anggotanya, akan menimbulkan kewibawaan pemimpin.

e. Fungsi Pengendalian

Fungsi pengendalian disebut juga kontroling atau pengawasan pemimpin, pengawasan yang bersifat pengendalian dilakukan pada saat kegiatan berlangsung, dengan maksud mencegah terjadinya penyimpangan atau kekeliruan dalam melaksanakan perintah atau keputusan pimpinan (Hadari Nawawi, 1993:149). Pencegahan adalah tindakan pengendalian jauh lebih baik, daripada harus memperbaiki kekeliruan atau kesalahan yang sudah terjadi, baik sengaja maupun tidak sengaja.

Pemimpin harus mampu menciptakan keseimbangan dalam rangka mencapai tujuan. Seorang pemimpin harus mampu menentukan mana yang perlu diprioritaskan dan mana yang perlu di tunda, sebagai pengambil keputusan seorang pemimpin dihadapkan kepada berbagai macam pendapat tentang kebijaksanaan organisasi (Widjaja, 1993:52). Tantangan terberat pemimpin adalah pengambilan kebijakan dalam kebijaksanaan.

Kehidupan organisasi adakalanya perselisihan pendapat, baik ditingkat intern maupun dalam tingkat ekstern, akibat perselisihan, mempunyai dampak semangat untuk bersaing atau malah sebaliknya penurunan para pekerja di bidangnya, dalam situasi seperti ini pemimpin perlu turun tangan sebagai seorang penengah untuk mengendalikan situasi. Seorang pemimpin harus berusaha untuk mengerti dan mempelajari segi-segi yang berkaitan tentang konflik, seperti proses terjadinya konflik, ciri-ciri konflik, sumber konflik, tingkat konflik, gaya manajemen konflik, serta peranan kepemimpinan dalam mengatasi konflik (Wahjosumidjo, 2005:48) f. Fungsi Keteladanan

Pemimpin merupakan tokoh sentral yang menjadi pusat perhatian, oleh karena itu pemimpin dituntut agar selalu menampilkan sikap dan perilaku yang baik sesuai dengan norma yang berlaku, karena sikap dan perilaku pemimpin akan diamati dan ditiru oleh anggotanya, yang berdampak dengan organisasi yang 
dipimpinnya. Oleh karena itu tidak ada pilihan lain bagi orang yang bersedia diangkat atau bersedia menjalankan peranan sebagai pemimpin, selain harus menjalankan kepemimpinan yang patut diteladani. Pemimpin dituntut menjadi teladan atau panutan dalam menjalankan disiplin waktu, disiplin kerja, moral dan semangat kerja, tanggung jawab, pengabdian, loyalitas, dan dedikasi, kecermatan dan ketelitian (Hadari Nawawi, 1993:151).

Kewibawaan pemimpin merupakan faktor penting dalam kehidupan kepemimpinan, karena dengan wibawa pemimpin dapat mempengaruhi perilaku orang lain baik secara berkelompok atau individu, sehingga orang tersebut mau melakukan apa yang telah dikehendaki pemimpin. Seorang bawahan akan tertarik apabila pemimpin dapat memberikan berbagai bentuk keteladanan yang positif, seperti jujur, sederhana, taqwa, selalu menepati janji, harga diri, jauh dari perbuatan tercela dan sebgainya. Jadi kewibawaan pemimpin ditentukan oleh sifat-sifat pribadi yang tercermin pada perilaku, kata-kata yang patut diteladani dan menjadi panutan (Widjaja, 1993:36).

3. Tipe-Tipe Kepemimpinan

Tipe kepemimpinan bisa disebut juga gaya kepemimpinan yang berarti sikap, gerakan, tingkah laku. Tipe atau gaya kepemimpinan adalah sekumpulan ciri yang digunakan pemimpin untuk mempengaruhi bawahan agar sasaran organisasi tercapai. Perwujudan tersebut biasanya membentuk suatu pola tertentu, denga tipe tertentu Pemimpin dapat mengantarkan institusi pada revolusi mutu (Baharuddin dan Umiarso, 2012:51). Tipe kepemimpinan digunakan sebagai pendekatan kepada bawahan untuk mensinergikan tujuan dengan cara mempengaruhi demi tercapainya tujuan yang telah ditetapkan.

Peran sentral dalam kehidupan pemimpin membuat suatu hal yang menarik untuk diamati dan diteliti, bagaimana, mengapa seorang pemimpin tersebut berhasil menggerakkan dan mempengaruhi untuk menjalankan perintahnya demi ketercapaian tujuan yang telah di tetapkan. Sifat-sifat, pola, tipe apa yang telah diterapkan pemimpin tersebut. Pada dasarnya tipe kepemimpinan menjadi faktor yang menentukkan keberhasilan organisasinya. Secara teoritis tipe kepemimpinan dapat dibedakan menjadi tiga, ketiga kepemimpinan dimaksud adalah sebagai berikut:

a. Tipe Kepemimpinan Otoriter

Pemimpin Otoriter bersikap sebagai penguasa dan yang dipimpin sebagai yang dikuasai, yang dilakukan pemimpin hanya memberi perintah, aturan dan larangan saja. Pemimpin otoriter biasanya bekerja keras, sunggguh-sungguh, teliti, dan tertib. Bekerja menurut peraturan-peraturan yang berlaku secara ketat dan instruksinya harus ditaati (Baaruddin dan Umiarso,2012:56) 
Kepemimpinan tipe ini menempatkan kekuasaan pada seseorang atau sekelompok kecil orang dan bertindak sebagai penguasa, karena berkuasa merasa dirinya sebagai yang paling mampu dan paling benar, sehingga tidak boleh dibantah. Tekanan berupa ancaman, sanksi dan hukuman dijadikan alat utama dalam melaksanakan kepemimpinannya (Hadari Nawawi, 1993:161). Anggapan bahwa dirinya lebih tinggi dari semua anggotanya, sedangkan orang-orang yang dipimpinnya sebagai pihak yang berada pada posisi yang lebih rendah. Tipe ini perilaku pemimpin selalu menetapkan keputusan sendiri, tanpa memberikan kesempatan anggotanya untuk memberikan saran-saran dan pendapatpendapat, sehingga anggota tidak ada kesempatan untuk menyampaikan kreativitas, dan inisiatifnya.

Seorang Otoriter tidak memberi kesempatan kepada bawahannya untuk berkembang, karena harus selalu mematuhi perintahnya, sehingga tipe kepemimpinan seperti ini akan menimbulkan ketidak nyamanan dalam menjalankan perintahnya, timbulnya perasaan tidak suka terhadap pimpinan tersebut, bahkan menimbulkan jurang pemisah yang berakibat terhadap etos kerja yang kurang baik.

b. Tipe Kepemimpinan Bebas (Laissez Faire)

Kepemimpinan Laissez Faire merupakan pola kepemimpinan yang lebih banyak percaya kepada anggotanya akibatnya sering membiarkan para bawahannya bekerja sesuka hatinya, sehingga fungsi kontroling kurang difungsikan. Tipe kepemimpinan ini kebalikan dari tipe kepemimpinan otoriter, pemimpin memberikan kebebasan kepada anggota dalam bertindak, yang terkadang menimbulkan kerancuan dalam pelaksanaan tugas, karena kurang perhatiannya dan pengawasan dari pemimpin.

Pemimpin dalam tipe ini memberikan kebebasan kepada semua anggota organisasi dalam menetapkan keputusan dan melaksanakannya menurut kehendak masing-masing (Hadari Nawawi, 1993:168). Akibatnya fungsi organisasi tidak berlangsung sebagaimana mestinya, bahkan menjadi tidak terarah dan simpang siur, karena pemimpin laissez faire setelah tujuan diterangkan kepada bawahannya, kemudian menyerahkan sepenuhnya pada bawahannya untuk menyelesaikan tugas yang menjadi tanggung jawabnya, dan hanya menunggu laporan tanpa adanya campur tangannya. Pada dasarnya keputusan pemimpin sangatlah dibutuhkan dalam organisasi sebagai acuan dan batasan dalam mengemban amanat.

Tipe kepemimpinan bebas pemimpin tidak merumuskan masalah serta cara pemecahannya, namun membiarkan yang dipimpinnya menemukan sendiri maslah yang berhubungan dengan kegiatan bersama dan mencoba mencari cara 
pemecahannya. Gaya ini hanya baik untuk kelompokorang yang betul-betul telah dewasa dan betul-betul paham akan tujuan dan cita-cita bersama (Baharuddin dan Umiarso, 2012:57).

c. Tipe Kepemimpinan Demokratis

Berdasarkan pada kata demokratis dapat disimpulkan bahwa setiap permasalahan yang timbul dilingkungan yang bersangkutan akan selalu dicari dan diselesaikan melalui musyawarah bersama. Kondisi yang seperti ini memberikan kesempatan kepada bawahannya untuk ikut andil dalam memberikan saran atau inisiatif dalam menentukan kebijaksanaan dalam kebijakan pemimpin. Kebijakan yang diambil dengan musyawarah akan berpengaruh kepada dukungan bawahan terhadap kebijakan tersebut, sehingga bawahan merasa ringan tanpa terbebani ketika melaksanakan tugasnnya, dan

\section{B. Pondok Pesantren}

\section{Pengertian Pondok Pesantren}

Pesantren dikenal nama pondok atau pondok pesantren. Istilah pondok berasal dari bahasa arab kata funduk yang berarti hotel atau asrama. Sedangkan pesantren berasal dari kata santri yang mendapat awalan Pe- dan akhiran -an yang berarti tempat tinggal santri. Istilah shastri yang dalam bahasa india yang berarti orang yang tahu buku-buku suci suci Agama Hindu (Zamakhsyari Dhofier, 1982:18). Pondok sebagai asrama santri dalam mengemban terciptalah suasana kerja yang saling pengertian, saling mendukung, selaras pemikirannya, dan harmonis.

Kepemimpinan demokratis pemimpin memandang anggotanya sebagai individu yang harus dihormati, dihargai, dan diakui hak dan kewajibannya (Hadari Nawawi, 1993:169). Dalam praktiknya pemimpin ini memanfaatkan setiap anggota dengan memberi kesempatan untuk berpartisipasi dalam kegiatan, sehingga anggota mendapatkan ruang untuk aktif. Sifat kepemimpinan demokratis adalah aktif dalam menggerakkan serta memotivasi dan dinamis dalam mengembangkan dan memajukan organisasinya. Wibawa pemimpin timbul karena pemimpin menghormati dan menghargai anggotanya, sehingga anggota segan kepa pemimpin demokratis.

ilmu, dengan adanya pondok santri akan lebih mandiri dalam melaksanakan kegiatan harian.

Menurut M. Bahri Ghazali (1996:22) Kedudukan pondok dalam suatu pesantren sangatlah berpengaruh terhadap pendidikan dan pengajarannya, karena santri tinggal di dalamnya sehingga lebih mudah untuk mengawasinya. Pondok sebagai wadah pendidikan manusia seutuhnya sebagai operasional dari pendidikan yakni mendidik dan mengajar, mendidik secara keluarga berlangsung 
dipondok sedangkan pengajaran di kelas atau mushola, oleh karena itu pondok pesantren merupakan lembaga pendidikan yang pertama mengembangkan lingkungan hidup dalam arti kata pengembangan sumber daya manusia dari segi mentalnya.

Sebuah pesantren pada dasarnya adalah sebuah asrama pendidikan Islam tradisional dimana para siswanya tinggal bersama dan belajar di bawah bimbingan seorang guru lebih dikenal dengan sebutan Kyai. Asrama untuk para siswa tersebut berada pada lingkungan komplek pesantren dimana kyai bertempat tinggal, menyediakan masjid untuk beribadah untuk beribadah, ruang untuk belajar dan kegiatankkegiatan keagamaan yang lain. Pondok merupakn ciri khas tradisi pesantren (Zamakhsyari Dhofier, 1982:44)

Keadaan kamar pondok biasanya sangat sederhana, mereka tidur diatas lantai tanpa kasur hanya sebuah tikar. Papanpapan di pasang pada dinding untuk menyimpan koper dan barang-barang lain. Para santri tidak boleh tinggal di luar komplek pesantren, kecuali mereka yang berasal dari lingkungan sekitar, hal ini ditujukan supaya kyai lebih mudah mengawasi dan menguasai santri, karena kyai tidak hanya seorang guru namun pengganti ayah para santri yang bertanggung jawab dalam membina dan memperbaiki santri.

2. Tipologi Pondok Pesantren
Pondok pesantren sebagai pendidikan Islam mengalami perkembangan sesuai perubahan zaman. Adanya kemajuan ilmu pengetahuan dan teknologi berdampak pula pada pondok pesantren. Perubahan tersebut bukan berarti menghilangkan khas dari tradisi pesantren, namun lembaga ini tumbuh dan berkembang dari masyarakat untuk masyarakat. Menurut M. Bahri Ghazali (1996:14) terbentuk dua tipe pondok pesantren yaitu:

a. Pondok Pesantren Tradisional

Pondok pesantren ini tetap mempertahankan bentuk aslinya dengan semata-mata mengajarkan kitab yang ditulis oleh ulama abad 15 dengan menggunakan bahasa arab. Pola pengajarannya menerapkan sistem halaqoh (belajar dibawah bimbingan guru) yang dilaksanakan di masjid, langgar atau surau.

b. Pondok Pesantren Modern

Pondok pesantren ini merupakan perkembangan tipe pesantren karena orientasi belajarnya cenderung mengadopsi sistem belajar klasik dan meninggalkan sistem belajar tradisional. Penerapan sistem belajar modern ini tampak pada penggunaan kelas-kelas belajar baik dalam bentuk madrasah maupun sekolah, kurikulum yang dipakai adalah kurikulum sekolah atau madrasah yang berlaku secara nasional

3. Elemen-Elemen Penting Pesantren Pondok, masjid, santri, kyai dan Pengajaran kitab-kitab Islam klasik 
merupakan elemen penting keberadaan pondok, kelima unsur ini dimiliki oleh setiap pondok, mulai dari pondok dengan jumlah santri yang sedikit atau pondok kecil sampai ke podok besar yang mempunyai santri yang banyak. Elemen-elemen tersebut menjadi tradisi pesantren, yang menunjukkan perkembangan dari lembaga pendidikan islam tersebut. Menurut Zamakhasyari Dhofier (1982:44) elemenelemen dasar dari tradisi pesantren adalah :

\section{a. Pondok}

Sebuah pesantren pada dasarnya adalah sebuah asrama pendidikan Islam tradisional dimana para siswanya tinggal bersama dan belajar di bawah bimbingan seseorang guru yang dikenal dengan sebutan "Kyai". Komplek pesantren ini biasanya di kelilingi dengan tembok untuk dapat mengawasi keluar dan masuknya para santri sesuai dengan peraturan yang berlaku.

b. Masjid

Masjid merupakan elemen yang tak dapat dipisahkan dengan pesantren yang diangap sebagai tempat yang paling tepat untuk mendidik para santri, erutama dalam praktek sembahyang lima waktu, khutbah dan sembahyang jama'ah dan pengajaran kitab-kitab klasik.

c. Santri

Menurut tradisi pesantren santri dibedakan menjadi 2 kelompok :

1) Santri Mukim yaitu santri murid-murid yang berasal dari daerah yang jauh dan menetap dalam kelompok pesantren tersebut biasanya merupakan satu kelompok tersendiri yang memegang tanggung jawab mengurusi pesantren sehari-hari, mereka juga memikul tanggung jawab mengajar santri-santri muda tentang kitab-kitab dasar dan menengah.

2) Santri Kalong yaitu murid-murid berasal dari desa-desa di sekeliling pesantren, yang tidak menetap dalam pesantren. Untuk mengikuti pelajarannya di pesantren, mereka bolak-balik dari rumahnya sendiri.

d. Kyai

Kyai merupakan elemen yang paling esensial dari suatu pesantren ia seringkali bahkan merupakan pendirinya. Kyai adalah gelar yang diberikan oleh masyarakat kepada ahli agama Islam yang memiliki atau menjadi pimpinan pesantren dan mengajar kitab-kitab Islam klasik kepada santrinya. Dalam penyelenggaraan pendidikan pesantren, Kyai merupakan figur sentral yang memiliki otoritas untuk merencanakan menyelenggarakan dan mengendalikan seluruh pelaksanaan pendidikan.

e. Pengajaran Kitab-kitab Islam Klasik

Pengajaran kitab-kitab Islam klasik, terutama karangan-karangan ulama yang menganut faham Syafi'iyah (Pemahaman menurut Imam Syafi'i), merupakan satusatunya pengajaran formal yang diberikan dalam lingkungan pesantren. Tujuan utama ialah untuk mendidik calon-calon ulama. 
Kitab-kitab tersebut dikenal dengan sebutan kitab kuning seperti nahwu, fiqh, usul fiqh, hadits, tafsir, tauhid, tasawuf, tarikh dan balaghoh. Sistem yang diberikan adalah wetonan (menyimak), sorogan (Membaca), bandongan (meterjemahkan).

\section{Metode Penelitian}

Lokasi penelitian dilakukan di Desa Kerjo Kecamatan Kebonsari Kabupaten Madiun terletak di Provinsi Jawa Timur. Di desa ini terdapat banyak pondok pesantren salafi, namun hanya Pondok Modern Babussalam yang menggunakan sistem klasikal, dan disebut sebagai Pondok Modern. Pondok ini mengajarkan dua kurikulum yaitu kurikulum berdasarkan Kementerian Agama dan Kurikulum Pondok Modern Darussalam Gontor. Penelitian dilaksanakan pada bulan Pebruari sampai bulan Juni 2013. Peneliti membutuhkan lima bulan di Lapangan agar memperoleh data serta informasi yang relevan.

Berdasarkan permasalahan yang diajukan bentuk penelitian ini menggunakan pendekatan kualitatif, yang lebih menekankan analisisnya pada proses penyimpulan deduktif dan induktif serta pada analisis terhadap dinamika hubungan antar fenomena yang diamati, dengan menggunakan logika ilmiah (Saifuddin Azwar, 2004:5). Penelitian ini diharapkan dapat mengungkapkan berbagai informasi dengan deskripsi secara rinci dan mendalam tentang pola Kepemimpinan di
Pondok Modern Babussalam mulai tahun 2008 sampai tahun 2013.

Penelitian ini berjenis penelitian kualitatif deskriptif, yaitu dalam penelitian data yang dikumpulkan berbentuk kata-kata atau gambar, meliputi transkip-transkip interview, catatan lapangan, fotografi, videotapes, dokumen personal, memo, dan catatan resmi lainnya (Asmadi Alsa, 2004:40). Dengan ini peniliti berusaha mengumpulkan data dengan mengadakan wawancara terhadap pimpinan, staff atau bagian organisasi, serta santri dan santriwatinya. Data santri serta data pengajar di pondok modern babussalam sebagai dokumen resmi serta formasi dewan guru, serta dokumen-dokumen lainnya yang dapat membantu peneliti dalam menerangkan pola Kepemimpinan di Pondok Modern Babussalam

Sesuai dengan metode kualitatif dan sumber data yang dipergunakan, karena dalam memecahkan permasalahan ini peneliti tidak hanya menggunakan teori namun langsung kelapangan dan mengamati permasalahan dilapangan untuk pengambilan data. Maka teknik yang digunakan dalam penelitian ini meliputi :

\section{Wawancara}

Tahap pertama peniliti melakukan wawancara dengan Pimpinan Pondok Modern Babussalam, yang merupakan tokoh dan topik utama dalam penelitian ini. Tahap kedua melakukan wawancara dengan Staff atau bagian-bagian organisasi sebagai 
pembantu pimpinan dalam mengkoordinasi santri atau santriwati. Tahap terakhir wawancara dengan santri atau santriwati sebagai orang yang dibimbing dan diasuh oleh Pimpinan dan para staff pembantunya. Setelah dirasa informasi yang diinginkan cukup, maka langkah selanjutnya menyusun dan menggabungkan hasil wawancara dengan observasi dan dokumentasi. Penelitian ini menggunakan wawancara terbuka..

\section{Observasi}

Observasi adalah pengamatan yang dilakukan secara sengaja, sistemati mengenai fenomena sosial dengan gejalagejala psikis untuk kemudian dilakukan pencatatan (Joko Subagyo, 2004:63). Peneliti dalam hal ini melakukan Observasi yang bersifat non partisipatif yaitu pengamatan yang tidak terlibat secara langsung. Adapun yang diobservasi yaitu :

a) Untuk mengetahui secara langsung situasi dan kondisi di Pondok Modern Babussalam.

b) Agar mendapatkan hasil yang akurat peneliti mengamati langsung semua aktifitas di Pondok Modern Babussalam.

\section{Dokumentasi}

Dalam hal ini peneliti berusaha mencari tentang data santri pada tahun 2013, miftah sebagai majalah Pondok Modern Babussalam, peraturan-peraturan tertulis pondok, motto dan panca jiwa pondok, foto-foto bangunan dan kegiatan santri baik kegiatan formal maupun non formal, buku notulen dalam rapat yang telah dilakukan di Pondok tersebut, jadwal aktifitas atau rutinitas santri.

Di dalam penelitian ini bentuk validasi yang digunakan untuk menguji kebenaran data dengan menggunakan trianggulasi sumber penelitian, hal ini mengarahkan agar pengumpulan data lebih menggunakan beragam sumber data yang berbeda. Sebuah data akan lebih terukur kebenarannya apabila dibandingkan dengan data sejenis yang diperoleh dari sumber yang berbeda (HB Sutopo 2006:93).

a) Menggunakan sumber data yang beragam

Di dalam menjawab permasalahan menggunakan sumber data yang beragam dengan begitu hasilnya akan lebih akurat. Di sini sumber data yang digunakan yaitu hasil wawancara Pimpinan, staff dan santri Pondok Modern Babussalam, hasil observasi, data-data yang berupa dokumentasi Pondok Modern Babussalam.

b) Untuk mendapatkan hasil yang akurat

Untuk mendapatkan hasil yang akurat dibutuhkan dibutuhkan sumber yang beragam, oleh karena itu validasi ini menggunakan trianggulasi sumber.

Data-data yang telah dikumpulkan melalui proses wawancara, observasi, serta dokumentasi selain harus kedalaman serta kemantapan kajian juga kebenaran yang dapat dipertanggung jawabkan, maka peneliti harus bisa memilih serta menentukan cara-cara yang tepat untuk 
mengembangkan validitas data yang diperolehnya.

Sementara itu data-data dalam penelitian ini digunakan sebagai bahan trianggulasi sumber berasal dari data sekunder antara lain berupa data siswa tahun ajaran 2012-2013, formasi dewan guru, formasi organisasi, motto dan panca jiwa pondok modern, serta dokumen atau

laporan lain yang berhubungan dengan peristiwa yang telah terjadi di Pondok Modern Babussalam, serta data-data primer ang diperoleh dari hasil observasi di lapangan dan melalui wawancara dengan beberapa narasumber. Adapun proses trianggulasi sumber dapat dijelaskan sesuai dengan bagan di bawah ini :

Bagan 3.1: Trianggulasi Sumber

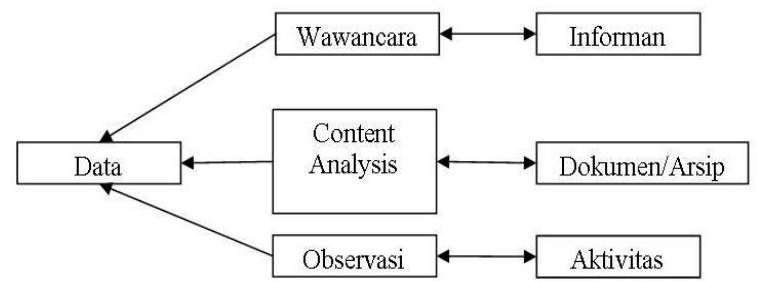

Sumber : HB Sutopo, 2006 : 94

Setelah data terkumpul, maka langkah selanjutnya adalah mengolah data yang telah diperoleh melalui penganalisaan terhadapa data yang telah terkumpul. Analisis data terdiri dari tiga komponen

\section{a) Reduksi Data}

Reduksi data merupakan komponen pertama dalam analisis yang merupakan proses seleksi pemfokusan, penyederhanaan, dan abstraksi dari semua jenis informasi yang tertulis lengkap dengan catatan lapangan (HB Sutopo, 2006:114). Dengan kata lain Reduksi data dapat pula diartikan sebagai proses pemilahan, pemusatan perhatian pada penyederhanaan, pengabstrakan dan transformasi data yang muncul dari catatan yaitu reduksi data, sajian data, dan penarikan simpula dengan verifikasinya, serta proses pengumpulan data di lapangan (HB Sutopo 2006:117). Langkah-langkah peneliti dalam menganalisi data yaitu :

dilapangan, sehingga dapat ditarik verifikasinya.

Peneliti memproleh data melalui wawancara, observasi serta dokumendokumen lain yang telah dikumpulkan dari Pondok Modern Babussalam kemudian melalui proses reduksi yaitu menggolongkan, mengarahkan serta membuang data-data yang tidak perlu dan mengorganisasi data yang telah diperoleh guna menarik sebuah interprestasi.

\section{b) Penyajian Data}


Sebagai komponen analisis kedua, sajian data merupakan rakitan informasi, deskripsi dalam bentuk narasi lengkap yang untuk selanjutnya memungkinkan simpulan penelitian dapat dilakuka. Sajian data ini disusun berdasarkan pokok-pokok yang terdapat dalam reduksi data, dan sajian dengan menggunakan kalimat dan bahasa peneliti yang merupakan rangkaian kalimat yang disusun secara logis dan sistematis, sehingga bila dibaca akan mudah dipahami (HB Sutopo 114-115).

Setelah data mengalami proses reduksi, langkah selanjutnya peneliti menyajikan atau menyiapkan data, penyajian data disusun berdasarkan pokokpokok atau inti yang terdapat dalam proses reduksi, kemudian dikembangkan menurut kalimat yang sesuai, sehingga lebih mudah dipahami. Penyajian data berisi gabungan dari berbagai data yang ditemukan di lapangan, sehingga peneliti dapat mengambil kesimpulan dan melakukan sebuah tindakan.

\section{c) Penarikan Kesimpulan atau Verifikasi}

Verifikasi merupakan aktifitas pengulangan untuk tujuan pemantapan, penelusuran data kembal dengan cepat, mungkin sebagai akibat pikiran kedua yang timbul melintas pada peneliti pada waktu menulis sajian data dengan melihat kembali sebentar pada catatan lapangan (HB Sutopo, 2006:116).
Dari data-data yang diperoleh dilapangan yang telah melalui reduksi dan telah disajikan dalam bentuk data kemudian untuk terkhir melalui proses penarikan kesimpulan atau verifikasi, pada tahapan ini data akhir dicek untuk yang terakhir sebelum dilaporkan secara keseluruhan.

\section{Hasil Penelitian dan Pembahasan}

\section{A. Sejarah dan Profil Pondok Modern} Babussalam

Pada tanggal 21 Syawal $1406 \mathrm{H}$ bertepatan dengan tanggal 29 Juni 1986 M dengan ucapan bismillah KH. Hadi Martoyo B.A mulai melangkah kaki untuk merintis sebuah pondok pesantren, ketika itu masyarakat sekitar dikumpulkan di sebuah mushola kecil, konon akan dijadikan sentral pondok pesantrennya. Ketika itu beliau menyampaikan cita-citanya kepada masyarakat serta pamit dan mohon doa restu untuk merintis sebuah pesantren, dengan bermodalkan niat, dan tawakal niat baik itu dirintis oleh KH. Hadi Martoyo B.A.

Suatu malam datanglah beberapa orang dan menyatakan diri untuk menyantri dan turut berjuang bersamanya, maka sejak malam itu pelajaran dimulai yang di tempatkan di Mushola. Pagi harinya santrisantri diajak meratakan tanah yang nantinya akan dibangun kelas di tanah warisan ke dua orang tuanya. Semakin hari semakin banyak santri yang mengaji dan belajar di mushola tersebut, sehingga pengajarannya diadakan di tempat terbuka, 
karena mushola tidak cukup untuk menampung santri yang bertambah kuantitasnya. Permasalahan pendanaan juga terjadi karena santri-santri belajar tidak dipungut biaya, sedangkan untuk pendidikan di perlukan dana seperti membeli kapur dan prasarana lainnya. Langkah yang ditempuh Pendiri Pondok adalah berkeliling menjual daun jeruk dan dibantu oleh santrinya, dari jualan tersebut dapat mencukupi biaya pendidikan

Kemudian pada tahun 1987 segala sesuatu mulai ditingkatkan, masuk kelas biasanya diadakan malam hari dirubah menjadi pagi hari, serta penambahan 2 ruang kelas, walaupun jumlah pengajar masih satu. Ruang tersebut sangat sederhana, karena dindingnya terbuat dari anyaman bambu dan atapnya terdiri dari rajutan daun tebu. Sedangkan mushola yang semula menjadi senter pengajaran menjadi dwifungsi yaitu sebagai asrama dan ruang belajar. Suasana pendidikan dan pengajaran lebih diintensifkan, disiplin harian, disiplin masuk kelas, disiplin bahasa, ukhuwah islamiyah dan ketertiban kamar telah diterapkan dalam kehidupan sehari-hari, walaupun masih jauh dari rencana.

Memasuki tahun 1988 santri yang datang berasal dari luar daerah bahkan luar pulau seperti Kalimantan, Sumatera, dan Sulawesi. Hal ini di sebabkan Pondok Modern Babussalam merupakan Pondok Alumni Gontor Darussalam, sehingga santri yang belum di terima oleh Pondok Modern
Gontor di tampung di Pondok Modern Babussalam. Pada tahun ini Pondok Modern Babussalam memperbaharui programprogram yang telah ada sebelumnya, khususnya dalam bidang pengasuhan santri. Keluar masuk kampung dilarang karena polusi mental yang ada pada masyarakat membahayakan santri. Kegiatan ekstrakulikuler mulai bermunculan seperti Muhadhoroh (Pidato), Pramuka, PPI ( Pusat Pengkajian Ilmu dan Informasi), serta rutinitas olahraga setiap sore hari. (Sumber: Wawancara Ust. Ahmadi, S.Pd.I, 6 Mei 2013).

Tahun 1989-1991 Babussalam terus mengadakan pembaharuan guna kebaikan dan kemajuan Pondok, pada tahun ini dibentuk organisasi pelajar dengan nama OSPM (Organisasi Santri Pondok Modern), pengurus diambil dari santri yang senior dan dibimbing oleh pengasuh maupun pimpinan. Hal ini ditujukan untuk kemasyarakatan santri dan kedewasaan serta menumbuhkan jiwa leadersheep pada santri. Tugas pengurus adalah mengontrol dan mengawasi kegiatan rutinitas santri, mulai bangun tidur sampai tidur lagi. Pada tahun ini pula diadakan penambahan ekstrakulikuler seperti EROB (English Resurrection of Babussalam), Drum Band, dan Kegiatan Jurnalistik "Kerja Post", PERSIBA (Persatuan Silat Babussalam).

Seiring berjalannya waktu Babussalam mencapai usia ke 8 tahun yang pada tahun tersebut, dapat meluluskan 5 
orang santri dan santriwati, 2 santri dan 3 santriwati. Santri tersebut mendapatkan pengabdian di Pondok Modern Gontor, Pondok Miftahussalam, dan sebagian di Pondok Babussalam. Fasilitas sebagai penunjang pendidikan sangat diperhatikan sehingga pada tahun 1992 Babussalam membangun sarana olahraga yaitu lapangan basket, dan sebuah toko usaha serta memperluas areal tanah di sekitar Pondok.

Tahun 1992-2000 Babussalam mengalami kejayaan, mulai dari pengajaran sampai pembangunan, selalu ada peningkatan setiap tahunnya. Di tahun 1992 dibangun Pondok Modern Babussalam Putri, yang letaknya tidak jauh dari Pondok Putra hanya sekitar $\pm 100 \mathrm{~m}$ untuk jarak tempuhnya, sehingga bisa ditempuh dengan jalan kaki. Kemajuan demi kemajuan mulai tampak, ini terlihat meningkatnya program pondok, dan banyaknya santri yang datang dari penjuru Indonesia. Catatan bersejarah bagi Pondok Modern Babussalam pada tanggal 17 Juni 1997 Drum Band Gita Babussalam Nada mendapat kepercayaan dari Istana Merdeka Republik Indonesia untuk tampil pada acara Parade Senja (Miftah 1997-1998:31). Pada tanggal 17 September 1997 tampil di Grahadi Surabaya.

Pondok Modern Babussalam mulai melebarkan kiprahnya dengan mendirikan Madrasah Ibtidaiyah dan Madrasah Tsanawiyah, dan sambutan masyarakatpun sangat menggembirakan, terbukti dengan banyaknya pendaftar, baik ke Mts ataupun MI. Pada tahun ke delapan Pondok Modern Babussalam mempunyai 6 lembaga pendidikan yaitu : KMI Putra, KMI Putri, MTs (Madrasah Tsanawiyah), MI, TK dan Madrasah Diniyah sore (Miftah 1997-1998 M:4). Dari tahun ke tahun ada lembaga yang tergeser seperti Diniyah sore ditiadakan, namun diganti dengan didirikannya MA (Madrasah Aliyah).

Kemajuan di bidang pendidikan membuat Babussalam untuk selalu eksis dan selalu meningkatkan kualitasnya di berbagai bidang, salah satunya peningkatan sarana transportasi sebagai armada untuk antar jemput siswa Tarbiyatul Athfal dan Madrasah Ibtidaiyah, dalam hal ini Babussalam membeli 2 Mini Bus yang di beri nama Hercules dan Paradise, serta 1 pick up yang diberi nama West.

Tahun 2000 adalah tahun duka bagi keluarga besar Pondok Modern Babussalam karena Pendiri sekaligus Pemimpin KH.Hadi Martoyo, B.A telah wafat. Sehingga seluruh jajaran lembaga yang ada sangat Berduka dan merasa kehilangan pemimpin yang sangat di seganinya. Kedudukan sebagai Pimpinan digantikan oleh keponakannya yang bernama Ust. Ahmad Fauzany Effendy, S.Ag, karena putra dari pendiri masih kecil. Tugas sebagai pemimpin ini merupakan Amanat terakhir dari Almarhum. Pulangnya Pendiri ke Rahmatullah, sangat berpengaruh dengan perkembangan pondok, hal ini terlihat berkurangnya 
kuantitas santri pada setiap tahunnya. Namun hal ini tidak menyurutkan Pemimpin dan Pengurus Babussalam untuk selalu berusaha menggapai masa keemasan kembali.

Pembangunan terus berlangsung guna menghadapi gejolak zaman yang mengunggulkan kemewahan gedung, untuk mengantisipasinya maka diadakan penambahan ruang kelas untuk Mts dan MA, serta pembangunan ruang kelas MI yang dulunya berdinding anyaman bambu dan beralaskan tanah, sekarang dibangun berdinding tembok, beralaskan keramik dan bangunannya bertingkat, walaupun

pembangunan masih terhambat karena keuangan.

Pembaharuan di bidang apapun selalu dilakukan untuk memajukan pondok, sampai pada tahun 2007 diadakan reuni akbar dari semua alumni yang tersebar di seluruh Indonesia, untuk saling tukar menukar pendapat demi kebaikan pondok. Akhir dari perkumpulan telah disepakati untuk membuat formasi badan wakaf, yang difungsikan sebagai pengawas Pondok, supaya lebih terkoordinir kembali. Hasil kesepakatan dari badan wakaf yaitu dibentuk 3 Pimpinan, 2 Direktur KMI dan rolling Kepala Lembaga.

Tabel 1

Formasi Pondok Modern Babussalam

\begin{tabular}{|l|l|l|l|}
\hline No & Formasi & Lama & Baru \\
\hline 1. & Pimpinan & $\begin{array}{l}\text { Ust. Ahmad Faunzani } \\
\text { Effendy, S.Ag. M.Pd.I }\end{array}$ & $\begin{array}{l}\text { Ust. Ahmad Faunzani } \\
\text { Effendy, S.Ag. M.Pd.I } \\
\text { Ust. Burhanuddin, S.Pd } \\
\text { Ust. Ahmadi MS, S.Pd.I }\end{array}$ \\
\hline 2. & Direktur KMI & $\begin{array}{l}\text { Ust. Burhanuddin, } \\
\text { S.Pd } \\
\text { Ust. Muhsin S.Ag }\end{array}$ & $\begin{array}{l}\text { Ust. Mukibbudin, M.Ag } \\
\text { Ust. Muhsin S.Ag }\end{array}$ \\
\hline 3. & Kepala Sekolah MA & $\begin{array}{l}\text { Ust. Suwarno, S.Ag, } \\
\text { M.Pd.I }\end{array}$ & Ust. Suwarno, S.Ag, M.Pd.I \\
\hline 4. & Kepala Sekolah MTs & $\begin{array}{l}\text { Ust. Mukibbudin, } \\
\text { M.Ag }\end{array}$ & Ust. Daman Huri, S.Pd \\
\hline 5. & Kepala Sekolah MI & $\begin{array}{l}\text { Ust. Ahmadi MS, } \\
\text { S.Pd.I }\end{array}$ & $\begin{array}{l}\text { Ust. Arif Fatkurrahman, } \\
\text { S.H.I }\end{array}$ \\
\hline 6. & Kepala Sekolah TA & $\begin{array}{l}\text { Ust. Amin } \\
\text { Mudawamah }\end{array}$ & Ust. Amin Mudawamah \\
\hline
\end{tabular}

(Sumber : Wawancara Ust. Burhanudin, S.Pd (Pimpinan), 7 Mei 2013)

Pondok Modern Babussalam setelah dibentuknya 3 Pimpinan mempunyai beberapa program baru yaitu posdaya dan pemahaman Al-Qur'an. Posdaya adalah layanan kesehatan masyarakat yang diadakan setiap satu bulan sekali, yang diprioritaskan kepada lanjut usia dan para ibu hamil atau balita tanpa di pungut biaya 
sepeserpun. Masalah dana untuk menyelenggarakannya di dapatkan dari donatur.

Pemahaman Al-Qur'an merupakan program belajar baru yang menitik beratkan kepada pemahaman Al-Qur'an melalui tarjamah, cara belajarnya seperti ngaji kitab-kitab klasik, pimpinan menyuruh seorang santri untuk membaca ayat sekalian dengan artinya, sehingga santri tidak hanya lancar membaca namun dapat memahami apa yang dimaksud dari setiap makna yang terdapat dari Al-Quran.

Kurikulum di Pondik Modern Babussalam adalah perpaduan antara pelajaran pondok dan MTs/MA, maka pelajaran yang diberikan secara keseluruhan adalah :

1. Program Umum : Tauhid, Adyan, Tafsir, Tarjamah, Tajwid, Hadits, Mutholaah, Fiqh, Usul Fiqh, Faroid, Bidayatul Mujtahid, Bahasa Indonesia, PPKn, Olah Raga dan Kesehatan, Tata negara, Ekonomi, Sejarah, Geografi, Sosiologi, Matematika, Biologi, Kimia, Fisika.

2. Program Penunjang : Bahasa Arab, Nahwu, Shrof, Balaghoh, Mutholaah, Mahfudzot, Insya', Imla', Khot, Bahasa Inggris, Grammar, Composition, Sejarah Indonesia, Sosiologi, dan Antropologi, Ekonomi, dan Geografi.

3. Program Khusus : Tarikh Islam, Sejarah Peradaban Islam, Tarbiyah, Ta'lilul Muta'alim (Sumber: Wawancara Ustd.
Mita Cahyani selaku Staff KMI, 7 Mei 2013)

Pondok Modern Babussalam suatu lembaga pendidikan Islam yang memberi kesempatan kepada santriwatinya untuk mengikuti Ujian Negara sebagai persamaan MTs/MA. Jenjang pendidikan yang diterapkan 6 tahun bagi lulusan SD/MI dan sederajatnya, dan 4 tahun bagi lulusan SMP/MTs dan sederajatnya yang dinamakan kelas Intensif. Bagi santri dan santriwati yang menyelesaikan sampai kelas 6 akan mendapatkan ijazah pondok yang disebut Syahadah.

Santriwati tingkat akhir akan menyelesaiakan beberapa ujian, yaitu ujian syafahi (lisan) gelombang I dan II, ujian tahriri (tulis) gelombang I dan II, Study Tour, karya tulis ilmiah yang di sebut paper. Ujian tahriri dan syafahi gelombang I materi yang diujikan pelajaran pondok mulai kelas I sampai kelas $\mathrm{V}$, gelombang II materi yang diujikan pelajaran pondok kelas 6 semester I dan II. Santri kelas V setiap bulan puas diadakan Fathul Kutub (bedah buku) serta munaqosah (diskusi), membahas tentang hukum-hukum Islam.

Babussalam merupakan Pondok yang penuh kegiatan mulai dari bangun tidur sampai tidur lagi, namun kegiatan tersebut membuat santri merasa senang karena kegiatannnya mengasyikkan. Kegiatan harian santri tersusun secara terperinci, dan setiap kegiatan sudah terkontrol oleh bagian masing-masing. 
Seluruh kegiatan ditujukan untuk mendidik santri supaya mandiri dan disiplin, bagi santri yang melanggar atau terlambat dalam mengikuti kegiatan akan dikenakan sanksi, berupa hafalan, membersihkan ruangan, atau di jemur, apabila kesalahan selalu diulangi dengan batasan yang sudah ditentukan pengurus, maka santri akan digundul dan santriwati akan mengenakan jilbab pelanggaran. Jilbab hijau melanggar Bagian Keamanan, jilbab orange melanggar Bagian Bahasa, jilbab merah melanggar bagian pengajaran, jilbab kuning melanggar bagian pengasuhan. Hukuman dianggap berat bagi santri namun hal ini tetap di jalankan, karena Pondok Modern Babussalam berprinsip “Disiplin itu pahit tapi lebih pahit kalau tidak ada disiplin. Sebelum hukuman berat (digundul dan dikenakan jilbab pelanggaran) diberikan kepada santri, pengurus organisasi berkonsultasi kepada bagian pengasuhan dan bagian pengasuhan konsultasi kepada Pimpinan, konsultasi kepada pimpinan merupakan interaksi untuk memutuskan kebijaksanaan dalam suatu kebijakan di Pondok Modern Babussalam.

Kegiatan Mingguan santri ditujukan untuk kegiatan tahunan seperti latihan pidato 3 bahasa, latihan drum band, pencak silat, MC (Master Of Ceremony), pramuka, Band.

Tabel 2

Kegiatan Mingguan Pondok Modern Babussalam

\begin{tabular}{|l|l|l|l|l|}
\hline No & Nama Kegiatan & Hari & Waktu & $\begin{array}{l}\text { Penanggung } \\
\text { Jawab }\end{array}$ \\
\hline 1. & $\begin{array}{l}\text { Latihan Drum } \\
\text { Band }\end{array}$ & $\begin{array}{l}\text { Sabtu dan } \\
\text { Minggu }\end{array}$ & $\begin{array}{l}14.00- \\
16.00 \mathrm{WIB}\end{array}$ & $\begin{array}{l}\text { Ust. } \\
\text { Ngainurrofiq }\end{array}$ \\
\hline 2. & $\begin{array}{l}\text { Latihan Pidato } \\
\text { Bahasa Inggris }\end{array}$ & Senin & $\begin{array}{l}12.30- \\
13.30 \mathrm{WIB}\end{array}$ & $\begin{array}{l}\text { Bagian } \\
\text { Pidato } \\
\text { dan OSPM }\end{array}$ \\
\hline 3. & Latihan Band & Selasa & $\begin{array}{l}15.15- \\
16.00 \mathrm{WIB}\end{array}$ & $\begin{array}{l}\text { Bagian } \\
\text { Musik }\end{array}$ \\
\hline 4. & Latihan Pidato & Kamis & $\begin{array}{l}11.00- \\
12.15 \text { WIB }\end{array}$ & $\begin{array}{l}\text { Bagian } \\
\text { Pidato dan } \\
\text { OSPM }\end{array}$ \\
\hline 5. & Latihan Pramuka & Kamis & $\begin{array}{l}13.30- \\
16.30 \text { WIB }\end{array}$ & $\begin{array}{l}\text { Mabikoord } \\
\text { dan } \\
\text { koordinator }\end{array}$ \\
\hline 6. & $\begin{array}{l}\text { Latihan Pidato } \\
\text { Bahasa } \\
\text { Indonesia }\end{array}$ & Kamis & $\begin{array}{l}20.00- \\
21.00 \text { WIB }\end{array}$ & $\begin{array}{l}\text { Bagian } \\
\text { Pidato dan } \\
\text { OSPM }\end{array}$ \\
\hline
\end{tabular}

(Sumber: Wawancara Ustd . Desi Novita Sari (Staff Pengasuhan), 7 Mei 2013) 
Ekstrakurikuler yang terdapat di Pondok Modern Babussalam merupakan wadah untuk mendidik generasi muda yang mempunyai talenta, yang nantinya dapat digunakan untuk menghadapi persaingan zaman. Pelaksanaan kegiatan ini tidak lepas dari kontrol Pimpinan, Pengasuh serta Pengurus yang ada di Pondok Modern Babussalam. Tugas Pengurus untuk mengawasi pelaksanaan pidato dan mengkoreksi naskah-naskah pidato, tugas Pengasuh keliling setiap minggu dalam latihan pidato santri, tugas Pimpinan memberi instruksi dan kontrol setiap saat, supaya tercipta keharmonisan dalam berorganisasi.

Santri dan Santriwati sangat bersemangat setiap latihan pidato, karena bagi santri yang bagus dalam berpidato setiap minggunya akan di lombakan ke Lomba pidato 3 bahasa, dan bagi pemenang akan mendapatkan piala dan piagam, sehingga hal ini menjadi pemicu semangat santri dalam berkompetisi. Lomba pidato 3 bahasa merupakan kegiatan tahunan Pondok Modern Babussalam, selain itu di Pondok Modern Babussalam mempunyai kegiatan tahunan yaitu Perkemahan Akbar selama 3 hari, PG (Panggung Gembira), DA (Drama Arena) Berbahasa Inggris dan Arab, Apel Tahunan, Fashion Show, Study Tour bagi Santri kelas akhir.

Pimpinan Pondok Modern

Babussalam selalu mendukung kegiatan santri selama kegiatan tersebut bersifat positif, hal ini ditunjukkan dengan adanya dukungan yang diapresiasikan keterlibatan Pimpinan di lapangan seperti keikut sertaan Pimpinan dalam pembuatan panggung gembira, serta keliling latihan drama sebelum pentas dimulai. Ketika Pimpinan keliling selalu memberi motivasi kepada santri dan santriwati untuk selalu bersemangat dalam latihan dan jaga kesehatan di tengah-tengah padatnya kegiatan, bagi beliau "Akal yang sehat terletak pada badan yang sehat".

Kekompakan 3 Pimpinan terlihat dalam suatu acara, seperti dalam perkemahan akbar terdapat pembagian tugas demi kelangsungan acara, Ust. Burhanuddin sebagai Pembina upacara pembukaan, Ust. Ahmadi sebagai Pembina upacara penutupan, dan Ust. Ahmad Fauzani Effendy memberikan sambutan dalam acara unggun gembira. Acara apel tahunan 3 Pimpinan menaiki panggung untuk memberikan sambutan serta menegaskan meskipun terdapat 3 pimpinan namun kebersamaan selalu terjaga, semua keputusan akan dimusyawarahkan bersama demi terciptanya kebijaksanaan. Setiap anggaran acara yang diajukan harus menyetujui 2 Pimpinan.

Formasi dewan guru di Pondok Modern Babussalam setiap tahunnya selalu berubah, dikarenakan adanya sebagian dari alumni diabdikan untuk pengabdian wajib 1 tahun, dan setelah 1 tahun pengabdian terkadang ada yang pulang ke Daerah asal, 
atau ingin melanjutkan study kembali di luar daerah, terkadang ada rolling bagi guru senior dan terkadang ada penambahan bagian-bagian formasi.

Selain evaluasi mingguan dan bulanan ada evaluasi tahunan yang mana dalam evaluasi tersebut membahas kegiatan tahunan yang sudah dilalui, dan menyusun kembali agenda tahun yang akan datang, dalam menentukan kegiatan tahunan harus berdasarkan persetujuan 3 Pimpinan, yang mana 3 Pimpinan harus hadir dalam evaluasi tahunan, yang diadakan ketika liburan semester 2. Evaluasi bagi 3 Pimpinan diadakan oleh badan wakaf setiap 3 tahun sekali, supaya Pondok Modern Babussalam lebih terkoordinir kembali.

Mulai tahun berdiri sampai sekarang santri dan santriwati yang ada di Pondok Modern Babussalam mengalami pasang dan surut. Kejayaan Pondok Modern Babussalam ketika pendiri K.H. Hadi Martoyo, B.A masih hidup, namun setelah beliau wafat kesurutan dari segi kuantitas mulai dirasakan oleh keluarga Pondok Modern Babussalam, terutama santri putra yang sangat berkurang sekali, karena ada kelas yang jumlahnya 1 atau 2 orang saja, untuk menindak lanjuti kuantitas yang semakin menurun, akhirnya pada pertengahan tahun pelajaran 2011-2012 Pimpinan memutuskan antara putra dan putri digabung untuk kegiatan belajar mengajarnya, hal ini sudah dimusyawarahkan dan disepakati oleh 3 Pimpinan.

Kuantitas yang sedikit tidak menyurutkan Pengajar untuk selalu memberikan ilmunya. Perjuangan dan ketulusan Pengajar Babussalam sangat tampak, Pengajar Babussalam mengajar tanpa upah atau imbalan, namun semangatnya patut untuk diteladani. Pada tahun pelajaran 2008-2013 santri Pondok Modern Babussalam mengalami labiltas, dan pada tahun ini jumlah santri Pondok Modern Babussalam mencapai 72. Santri Babussalam semakin tahun semakin berkurang kuantitasnya, berbagai upaya ditingkatkan untuk menarik santri supaya tertarik dengan Pondok Modern Babussalam. Usaha untuk meningkatkan kuantitas cukup membuahkan hasil terlihat dari data diatas yang pada tahun 2009 sampai 2012 mengalami penurunan, dan di tahun 2013 mengalami kenaikaan walaupun jauh dari harapan.

\section{B. Pola Kepemimpinan di Pondok Modern Babussalam}

Pemimpin merupakan orang pertama dalam organisasi, ibarat tubuh pemimpin adalah otak yang mempunyai inisiatif dan menugaskan ke organ tubuh untuk menjalankan apa yang diinginkan tubuh, begitu pentingnya pemimpin dalam organisasi, berhasil atau tidaknya tujuan organisasi terletak pada pemimpinnya. Pemimpin harus mempunyai suatu 
kelebihan supaya anggotanya menghormati dan segan kepadanya, sehingga tercipta fungsi instruksi, delegasi, konsultatif, partipasi dan fungsi pemimpin yang lain, serta hubungan kerjasama akan terjalin dengan baik.

Kelebihan Pemimpin bisa dengan cara berpikir, dalam kerohanian dan dalam kejasmaniannya (Widjaja,1985:25). Pemimpin merupakan teladan yang tingkah lakunya dan perbuatannya akan ditiru serta menjadi sorotan oleh anggotanya. Sama halnya dengan Pemimpin Pondok, harus mempunyai kelebihan yang nampak, dan pengetahuan yang luas sehingga para santri menghormatinya. Pemimpin yang bijak akan disegani oleh anggotanya. Kelebihankelebihan ini dapat dimiliki melalui pengalaman atau pendidikan.

Pondok Modern Babussalam mempunyai 3 Kepemimpinan yaitu Ust. Ahmad Fauzani Effendy, S.Ag, M.Pd.I, Ust. Burhanudin, S.Pd, Ust. Ahmadi, S.Pd.I. Kerjasama antara ketiga pimpinan yaitu dengan saling mengisi kekosongan dalam kegiatan pondok, seperti memberikan sambutan atau pelepasaan dalam suatu acara. Setiap keputusaan untuk kegiatan akan diputuskan bertiga melalui musyawarah. Fungsi Pimpinan di Pondok Modern Babussalam adalah sebagai berikut:

\section{Fungsi Intruktif}

Kemampuan intruksi atau perintah perlu dimiliki Pemimpin dengan memberikan perintah secara jelas agar perintah tersebut mampu dilaksanakan anggotanya dengan baik. Komunikasi yang baik dan jelas sangat mempengaruhi hasil dari apa yang telah di perintahkan, hendaknya seorang pemimpin mempunyai interaksi yang baik kepada anggotanya. Pemimpin harus menetapkan apa, bagaimana, bilamana, dan di mana suatu perintah dilaksanakan (Hadari Nawawi, 1993:143). Bawahan atau anggota harus menjalakan apa yang telah di perintahkan, karena Pemimpin memiliki kekuasaan untuk meminta bawahan dan bawahan mempunyai kewajiban untuk menuruti atau mematuhinya.

Pemimpin Pondok Modern Babussalam memberikan perintah yang baik dan sesuai dengan Syariat Islam, sebagai contohnya adalah dalam menentukan formasi dewan guru dan pengurus, Pemimpin memberi amanat untuk menentukan siapa saja yang pantas mengemban bagian tersebut, yang nantinya akan diolah kembali oleh 3 Pimpinan. Pemimpin Pondok Modern Babussalam memberikan perintah kepada ustad, ustadah,serta santri dan santriwatinya perintah dalam lingkup pendidikan dan keagamaan demi tercapainya visi dan misi pondok.

\section{Fungsi Konsultatif}

Fungsi konsultatif yaitu Pemimpin perlu menyimak berbagai persoalan, aspirasi, pendapat, perasaan, data, informasi dan lain-lain yang diungkapkan anggotanya. 
Dorongan serta solusi yang baik dan tepat adalah faktor yang mempengaruhi efektifitas seorang pemimpin. Pemimpin harus mampu menciptakan keseimbangan, mampu menentukan mana yang diprioritaskan dan mana yang ditunda. . Fungsi ini seorang pemimpin memberikan saran dalam pemecahan masalah serta memberikan sumbangan informasi dan pendapat (Wahjosumidjo, 2005:41).

Permasalahan Pondok selalu ada baik dari dewan gurunya maupun santrinya, yang paling sering muncul terletak pada santri dan santriwatinya. Ketika dewan guru terutama Staff Pengasuhan menemui masalah seperti adanya kasus santri mencuri uang temannya atau sering melanggar bahasa, hukuman atau sanksi seperti apa yang pantas bagi pelanggar, maka semua permasalahan tersebut akan di konsultasikan kepada pimpinan terlebih dahulu. Segala aspek yang menyangkut urusan pondok akan dikonsultasikan dulu kepada Pimpinan.

\section{Fungsi Partisipasi}

Tugas pemimpin dalam fungsi partisipatif adalah mengerahkan tim kepada ketercapaian konsensus (Baharuddin dan Umiarso, 2012:54). Tujuan adalah sebagai pedoman dalam organisasi, segala aspek mengacu atau berkiblat kepada tujuan organisasi, yang pada akhirnya menjadi pondasi pemimpin dalam melaksanakan tugasnya untuk mengerahkan timnya, dan membina team work yang solid.
Keikutsertaan Pimpinan Pondok Modern Babussalam sangatlah nampak, karena Pimpinan tidak hanya menyuruh namun juga terlimbat langsung, seperti dalam pengajaran santri, 3 pimpinan juga mempunyai jadwal mengajar, dalam suatu kegiatan besar seperti membuat panggung, terlihat salah satu diantara 3 Pimpinan membantu pembuatan panggung, demi kelancaran acara tersebut.

\section{Fungsi Delegasi}

Delegasi adalah melimpahkan sebagian wewenang kepada orang yang dipercayainya seperti staff, divisi atau bawahannya, hal ini ditujukan untuk mempermudah pekerjaan pemimpin dalam mengemban tugasnya, fungsi delegasi juga bisa disebut pembagian tugas terhadap staff dan bawahannya. Hal ini telah dilaksanakan oleh Pimpinan Pondok Modern Babussalam dengan membuat formasi dewan guru beserta pembagian tugas setiap bagiannya.

Kepercayaan kepada para staffnya merupakan pondasi dalam menjalankan semua peraturan yang ada di Pondok, sehingga kepercayaan tersebut dijaga oleh anggotanya, sehingga tercipta keselarasan antara Pimpinan dan ustad maupun ustadahnya dalam berorganisasi dan mendidik santri-santinya. Kepercayaan Pimpinan dianggap amanat yang harus dijaga dan dilaksanakan. Pemimpin harus mampu memberikan kepercayaan, sedang penerima delegasi harus mampu 
memelihara kepercayaan (Hadari Nawawi, 1993:147).

\section{Fungsi Pengendalian}

Fungsi pengendalian disebut juga kontroling atau pengawasan pemimpin, pengawasan yang bersifat pengendalian dilakukan pada saat kegiatan berlangsung, dengan maksud mencegah terjadinya penyimpangan atau kekeliruan dalam melaksanakan perintah atau keputusan pimpinan (Hadari Nawawi, 1993:149). Kehidupan organisasi adakalanya perselisihan pendapat, baik ditingkat intern maupun dalam tingkat ekstern, akibat perselisihan, mempunyai dampak semangat untuk bersaing atau malah sebaliknya penurunan para pekerja di bidangnya, dalam situasi seperti ini pemimpin perlu turun tangan sebagai seorang penengah untuk mengendalikan situasi.

Perselisihan selalu terjadi karena beda kepala beda pemikiran juga, ketika perselihan itu terjadi pemimpin pondok tampil sebagai penengah, suatu ketika dalam musyawarah perkemahan akbar yang diadakan oleh segenap panitia MI dan KMI Babussalam terjadi perselisihan di dalam iuran peserta antara MI dan KMI, yang akhirnya menimbukan konflik, dalam menghadapi ini Ust. Burhanudin sebagai salah satu Pemimpin Pondok, berusaha mengambil titik tengah dari permasalahan, dan akhirnya apa yang telah disampaikan Pemimpin tersebut menjadi keputusan akhir dari musyawarah.

\section{Fungsi Keteladanan}

Pemimpin merupakan tokoh sentral yang menjadi pusat perhatian, oleh karena itu pemimpin dituntut agar selalu menampilkan sikap dan perilaku yang baik sesuai dengan norma yang berlaku, karena sikap dan perilaku pemimpin akan diamati dan ditiru oleh anggotanya, yang berdampak dengan organisasi yang dipimpinnya. Kewibawaan pemimpin merupakan faktor penting dalam kehidupan kepemimpinan, karena dengan wibawa pemimpin dapat mempengaruhi perilaku orang lain baik secara berkelompok atau individu, sehingga orang tersebut mau melakukan apa yang telah dikehendaki pemimpin. Kewibawaan pemimpin ditentukan oleh sifat-sifat pribadi yang tercermin pada perilaku, kata-kata yang patut diteladani dan menjadi panutan (Widjaja, 1993:36).

Suri tauladan telah diberikan oleh Pimpinan Pondok Modern Babussalam, baik dibidang keagamaan, pendidikan dan harian. Dibidang keagamaan beliau selalu menjadi imam untuk sholat ima waktu, dan ketika sholat subuh beliau berangkat ke mushola lebih awal dan berdiri di depan mushola, sehingga santri-santri menjadi segan kalau terlambat untuk berjamaah. Di bidang pendidikan beliau mengajar tanpa buku, karena beliau hafal diluar kepala serta paham, Ust. Burhan di bidang bahasa inggris, Ust. Fauzany di bidang tafhimul Qur'an dan bahasa arab, Ust. Ahmadi di 
bidang tauhid dan fiqh, karena kemahiran tersebut santri-santri merasa segan dan taat kepada Pimpinan. Keseharian Pimpinan dapat dijadikan tauladan busana yang sopan dan menutup aurat, tutur kata yang santun dan selalu menggunakan bahasa resmi ketika berinteraksi dengan santri dan asatidah.

Ditinjau dari uraian di atas melalui fungsi-fungsi kepemimpinan yang telah dilaksanakan, dapat untuk menarik kesimpulan dari tipe kepemimpinan. Tipe kepemimpinan bisa disebut juga gaya kepemimpinan yang berarti sikap, gerakan, tingkah laku. Tipe atau gaya kepemimpinan adalah sekumpulan ciri yang digunakan pemimpin untuk mempengaruhi bawahan agar sasaran organisasi tercapai. Tipe kepemimpinan digunakan sebagai pendekatan kepada bawahan untuk mensinergikan tujuan dengan cara mempengaruhi demi tercapainya tujuan yang telah ditetapkan. Pada dasarnya tipe kepemimpinan menjadi faktor yang menentukkan keberhasilan organisasinya.

\section{Pemimpin Pondok Modern} Babussalam terdapat 3 orang, mempunyai karakteristik yang berbeda, namun dalam kepemimpinannya mampu untuk menyamakan langkah. Ust. Burhan merupakan sosok Pemimpin yang tegas dan disiplin, sama seperti Ust. Fauzani yang tegas, disiplin dan bijaksana dalam setiap tutur katanya, sedangkan Ust. Ahmadi sesosok pemimpin yang penuh dengan pengertian dan lembut dalam tutur katanya, namun dibalik kelembutannya dalam kepemimpinan belau sangat tegas apabila menemui hal yang kurang sesuai. Ketiga pimpinan selalu mengutamakan sistem musyawarah dalam menentukan berbagai hal, baik musyawarah dengan para pengasuh atau sesama pimpinan.

Berdasarkan dinamika yang terjadi antara Pimpinan Pondok Modern Babussalam besera pengasuh sampai kepengurus dan santri, yang lebih mengedepankan musyawarah, dapat di tarik kesimpulan bahwa pola kepemimpinan di Pondok Modern Babussalam bersifat demokratis. Memberikan kesempatan kepada bawahannya untuk ikut andil dalam memberikan saran atau inisiatif dalam menentukan kebijaksanaan dalam kebijakan pemimpin, sehingga bawahan merasa ringan tanpa terbebani ketika melaksanakan tugasnnya, dan terciptalah suasana kerja yang saling pengertian, saling mendukung, selaras pemikirannya, dan harmonis.

Kepemimpinan demokratis pemimpin memandang anggotanya sebagai individu yang harus dihormati, dihargai, dan diakui hak dan kewajibannya (Hadari Nawawi, 1993:169). Wibawa seorang pemimpin akan tampak dan disegani oleh anggotanya. Pemimpin Pondok Modern Babussalam memanfaatkan setiap anggota dengan memberi kesempatan untuk berpartisipasi dalam kegiatan, sehingga 
anggota mendapatkan ruang untuk aktif. Sifat kepemimpinan demokratis yang ada pada Pemimpin Pondok tujuannya adalah untuk kebaikan dan kemajuan pondok, semakin banyak orang yang memikirkan pondok, maka semakin banyak orang yang menyayangi Pondok.

\section{Penutup}

\section{A. Simpulan}

Dari uraian hasil penelitian, dapat ditarik kesimpulan sebagai berikut:

1. Pondok Modern Babussalam mempunyai 3 Pimpinan, hal ini disebabkan terbentuknya badan wakaf yang telah disepakati dalam reuni akbar dari seluruh alumni Pondok Modern Babussalam, yang didalamnya membahas cara untuk meningkatkan kembali kuantitas santri. Dari badan wakaf tersebut menghasilkan keputusan dibentuknya 3 pimpinan, dengan tujuan untuk meringankan tugas dan peran pimpinan.

2. Fungsi Kepemimpinan di Pondok Modern Babussalam terlaksana dengan baik, seperti fungsi instruktif, fungsi konsultatif, fungsi partisipasi, fungsi delegasi, fungsi pengendalian, fungsi keteladanan. Setiap fungsi kepemimpinan dilaksanakan dengan cara membagi tugas dan mengisi kekosongan, sehingga fungsi tersebut dapat berjalan dengan baik, walaupun masih terdapat kendala dalam pelaksanaanya, namun antara pimpinan dapat menutupi atau mengcover kekurangan tersebut.

3. Pemimpin di Pondok Modern Babussalam bertipe demokratis, karena mengedepankan musyawarah dalam suatu kebijakan. Pemimpin Pondok memandang ustad dan ustadahnya sebagai seorang yang harus dihormati, dihargai, dan diakui hak dan kewajibannya, sehingga beliau selalu melibatkan anggotanya untuk suatu keputusan. Wibawa pemimpin timbul karena menghormati anggotanya. Karakter 3 Pimpinan sebenarnya berbeda, ada yang lembut, tegas, disiplin dan beberapa karakter yang berbeda, namun semua perbedaan karakter individu tersebut, tidak menjadikan permasalahan dalam suatu kebijakan, dan mampu utuk menyatukan langkah demi kebaikan dan kemanjuan pondok yang pernah merosot kuantitasnya, dan sekarang masih berupaya untuk lebih meningkatkan kembali.

\section{B. Saran}

1. Pada era globalisasi yang penuh dengan kemajuan ilmu dan teknologi serta arus meodernisasi trus mengalir, diharapkan pondok tidak meninggalkan fundamen islam sebagai tumpuan hidup setiap generasinya.

2. Pondok terkenal dengan Pendidikan Islam tradisional, diharapkan mampu bersaing dengan lembaga pendidikan 
formal lainnya, dan dapat melahirkan genarasi muda yang berpengetahuan luas dan berakhlaq mulia

3. Untuk mengembangkan kemanjuan pondok selain meningkatkan mutu pengajaran dan mutu pendidikan, perlu memperhatikan sarana dan prasarana seperti kelas, asrama, laboratorium, armada, sebagai penunjang kebutuhan yang ada di lapangan.

4. Untuk meningkatkan kemajuan lembaga di bidang kemajuan adalah

\section{Daftar Pustaka}

Abdurrahman Wahid. 2001. Menggerakkan Tradisi: Esai-Esai Pesantren. Yogyakarta: LKiS.

Azyumardi Azra. 1999. Konteks Berteologi di Indonesia: Pengalaman Islam. Jakarta: Paramadina. . 1989. "Jaringan Ulama Timur Tengah dan Indonesia Abad 17, sebuah esai untuk 70 tahun Prof. Dr. Harun Nasution" dalam Refleksi Pembaharuan Pemikiran Islam. Jakarta: LSAF.

Baudet, H. \& I.J. Brugmans (peny.). 1987. Politik Etis dan Revolusi Kemerdekaan. Yayasan Obor Indonesia, Jakarta.

Dawam Rahardjo (ed.), 1988. Pesantren dan Pembaharuan. Jakarta: LP3ES.

Hasbullah. 1999. Sejarah Pendidikan Islam di Indonesia: Lintasan Sejarah Pertumbuhan dan Perkembangan. Jakarta: PT Raja Grafindo Persada.

Lathiful Khuluq. 2000. Fajar Kebangunan Ulama, Biografi KH. Hasyim Asy'ari. Yogyakarta: LKiS.

Marzuki Wahid. “Ma'had Aly: Nestapa Tradisionalisme dan Tradisi Akademik yang Hilang", Makalah, disampaikan dalam Lokakarya Perencanaan meningkatkan tenaga pengajarnya, sebagai guru dituntut untuk menguasai materi pengajaran, hal ini dapat ditingkatkan dengan diklat atau melanjutkan ke jenjang perkuliahan.

5. Kemajuan Pondok terletak pada pemimpin, diharapkan dengan adanya 3 pimpinan Pondok Modern Babussalam mencapai kejayaannya kembali. Selalu terjaga kekompakan pimpinan dalam berbagai bidang.

Partisipatif Madrasah Aliyah Nahldatul Ulama Sragen dan Pesantren An-Najah Sragen pada 13 Oktober 2003.

Mastuhu. 1994. Dinamika Sistem Pendidikan Pesantren. Jakarta: INIS.

Muh. Said \& Juminar Affan. 1987. Mendidik dari Zaman ke Zaman. Jemmars, Bandung.

Nurcholis Madjid. 1997. Bilik-Bilik Pesantren. Jakarta: Paramadina.

Pradjarta Dirdjosanjoto. 1999. Memelihara Umat, Kiai Pesantren-Kiai Langgar di Jawa. Yogyakarta: LKiS.

Ricklefs, M.C. 1991. Sejarah Indonesia Modern. Yogyakarta: Gajah Mada University Press.

Soediyono, dkk. 1999. Laporan Penelitian Kelompok Kemandirian Pesantren, Studi Kelembagaan dan Pengelolaan Pendidikannya. Semarang: IAIN Walisongo.

S. Nasution. 2001. Sejarah Pendidikan Indonesia. Jakarta: Bumi Aksara.

Steenbrink, Karel A. 1986. Pesantren, Madrasah, Sekolah. Jakarta: LP3ES.

Van Bruinessen, Martin. 1995. Kitab Kuning, Pesantren dan Tarekat Tradisitradisi Islam di Indonesia. Bandung: Mizan. 
166 | JURNAL AGASTYA VOL 04 NO 02 JULI 2014

Zamakhsyari Dhofier. 1985. Tradisi Pesantren: Studi Tentang Pandangan Hidup Kyai. Jakarta: LP3ES.
Ziemek, Manfred. 1986. Pesantren dalam Perubahan Sosial. Jakarta: P3M 1983.

Zuhairini, dkk. 1997. Sejarah Pendidikan Islam. Jakarta: Bumi Aksara. 